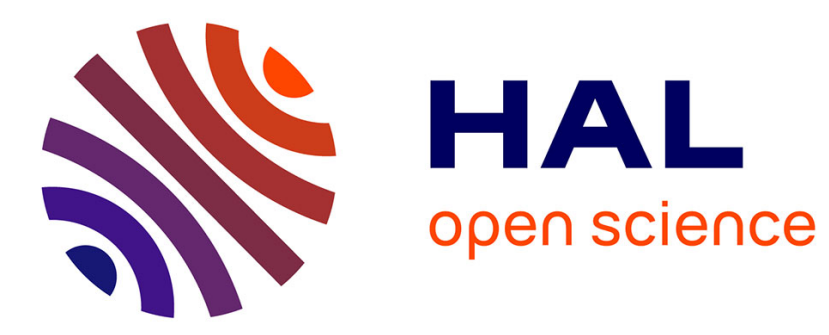

\title{
Apneic Oxygenation for Intubation in the Critically Ill. Let's Not Give Up!
}

\author{
Audrey de Jong, Samir Jaber
}

\section{To cite this version:}

Audrey de Jong, Samir Jaber. Apneic Oxygenation for Intubation in the Critically Ill. Let's Not Give Up!. American Journal of Respiratory and Critical Care Medicine, 2016, 193 (3), pp.230 - 232. 10.1164/rccm.201510-1998ED . hal-01793248

\section{HAL Id: hal-01793248 \\ https://hal.umontpellier.fr/hal-01793248}

Submitted on 3 Dec 2019

HAL is a multi-disciplinary open access archive for the deposit and dissemination of scientific research documents, whether they are published or not. The documents may come from teaching and research institutions in France or abroad, or from public or private research centers.
L'archive ouverte pluridisciplinaire HAL, est destinée au dépôt et à la diffusion de documents scientifiques de niveau recherche, publiés ou non, émanant des établissements d'enseignement et de recherche français ou étrangers, des laboratoires publics ou privés. 


\section{Apneic Oxygenation for Intubation in the Critically III Let's Not Give Up!}

In this issue of the Journal, Semler and colleagues (pp. 273-280) reported the effect of apneic oxygenation with $15 \mathrm{~L} / \mathrm{min}$ nasal cannula oxygen on the lowest oxygen saturation during the intubation procedure (1).

The authors performed a randomized trial in a medical intensive care unit (ICU), enrolling 150 patients. In the usual care group and in the apneic oxygenation group, respectively, 73 and 77 patients were included. The administration of $15 \mathrm{~L} / \mathrm{min}$ nasal cannula oxygen in the apneic oxygenation group was not associated with a significantly less drop in arterial oxygen saturation (from $92 \%$ in the apneic oxygenation group to $90 \%$ in the usual care group $[P=0.16])$. The authors concluded that apneic oxygenation does not increase the lowest arterial oxygen saturation during intubation in critically ill patients compared with usual care. 
In 1959, one study reported about eight patients scheduled for minor operations intubated and paralyzed to prevent breathing (2). Pure oxygen was administered in the endotracheal tube. The patients drastically increased their carbon dioxide tension (up to $250 \mathrm{~mm} \mathrm{Hg}$ ) and developed respiratory acidosis (up to a $\mathrm{pH}$ of 6.72 ) while maintaining $100 \%$ oxygen saturation. Indeed, whereas carbon dioxide tension depends on minute ventilation, oxygenation depends on positive end-expiratory pressure (PEEP) and $\mathrm{F}_{\mathrm{O}_{2}}$. The aim of using apneic oxygenation throughout the intubation procedure in ICUs would be to reduce the occurrence of severe hypoxemia and its associated complications (3), such as cardiac arrest (4). Indeed, if noninvasive ventilation can be used to enhance preoxygenation $(5,6)$, the mask has to be removed during the laryngoscopy, and the patient is deprived of oxygen during the procedure. Apneic oxygenation increased the time to severe desaturation during the intubation procedure in acute lung injury in an experimental study in piglets (7). Miguel-Montanes and colleagues (8) compared 3 minutes of preoxygenation using a nonrebreathing bag reservoir face mask with $60 \mathrm{~L} / \mathrm{min}$ of high-flow nasal cannula oxygen in patients with mild to moderate hypoxemia. With the face mask, the median lowest oxygen saturation as measured by pulse oximetry during intubation was $94 \%$ versus $100 \%$ with high-flow oxygen.

Contrary to the positive effects of high-flow nasal cannula oxygen reported in the study by Miguel-Montanes and colleagues (8) on the prevention of oxygen desaturation during intubation, Vourc'h and colleagues (9) did not report similar results. They found no difference on lowest arterial oxygen during intubation in hypoxemic patients between $60 \mathrm{~L} / \mathrm{min}$ of high-flow nasal cannula oxygen and 4 minutes of preoxygenation with a face mask (92\% vs. $90 \% ; P=0.44)$. Finally, among these three randomized studies $(1,8$, 9) that evaluated apneic oxygenation during tracheal intubation, only one study (8) reported superiority with high-flow nasal cannula oxygen, and two studies $(1,9)$ showed no significant difference between preoxygenation devices. The discrepancies between the results of these three studies $(1,8,9)$ could mainly be explained by the oxygen flow used for the apneic oxygenation group (from 15 to $60 \mathrm{~L} / \mathrm{min}$ ) and the different studied populations in term of hypoxemia. Efficacy of apneic oxygenation mostly depends on delivered $\mathrm{F}_{\mathrm{O}_{2}}$, oxygen flow, position of the patient, and degree of hypoxemia. High-flow oxygen therapy generates a flow-dependent positive airway pressure that could prevent extubation failure compared with Venturi mask (10). However, in the current study, oxygen was administered by nasal cannula with a flow of $15 \mathrm{~L} / \mathrm{min}$, which does not allow a positive airway pressure (11). As suggested by Semler and colleagues (1) in their discussion, increasing the flow of oxygen from 15 to $60 \mathrm{~L} / \mathrm{min}$ could improve apneic oxygenation. Moreover, the position of the mandible was not standardized, whereas subluxation of the temporomandibular joint during preoxygenation could improve oxygen diffusion by liberating the airway, displacing the tongue at a ventral position, and thus increasing the oropharyngeal space (12). Furthermore, mouth closing or opening during preoxygenation was not specified, whereas PEEP effect is only significant when the mouth is closed (11). Nor was the position of the patient during preoxygenation standardized, which influences the duration of nonhypoxic apnea after anesthetic induction. Similarly, the choice of preoxygenation devices as reported in Semler and colleagues' Table 1 (nonrebreather mask, bilevel positive airway pressure, bag-valve mask ventilation, standard nasal cannula) was left to the physicians' appreciation. This is also a confounding factor, given that noninvasive ventilation in hypoxemic patients has been shown to increase lowest oxygen saturation during intubation procedure (5).

In the study of Semler and colleagues (1), the lowest oxygen saturation was $91 \%$ in the usual care group versus $92 \%$ in the apneic oxygenation group. In the literature, reported lowest oxygen saturation during intubation procedure of hypoxemic patients is between 80 and $85 \%(5,13)$. Apneic oxygenation could particularly benefit to this specific population of hypoxemic patients. Further, patients in whom a specific laryngoscopy device was required, such as a video laryngoscope $(14,15)$, were excluded. In this population at risk for difficult intubation, apneic oxygenation could also be very relevant, given the potentially increased length of intubation associated with an increased incidence of hypoxemia. It is worth noting that hypoxemia per se is a factor of difficult intubation (13) and associated complications.

It bears noting that an important limitation of the study is the absence of a blinded design. Assessors of oxygen saturation could have been influenced by their own opinion. Another limitation, also related to the design, is the number of subjects needed, based on an optimistic hypothesis of a $4.6 \%$ difference between groups. The saturation in usual care being $91 \%$, the mean lowest oxygen saturation in the apneic oxygenation group should have been $96 \%$, which is very high for an intubation performed in an ICU (13).

To conclude, the study of Semler and colleagues (1) is a randomized nonblinded study showing there is no difference between apneic oxygenation with a flow of $15 \mathrm{~L} / \mathrm{min}$ nasal cannula oxygen and usual care in the lowest oxygen saturation experienced by nonselected critically ill adults undergoing endotracheal intubation. The effect of apneic oxygenation during intubation procedure in the ICU could interestingly be now assessed in a specific population of hypoxemic patients, particularly at risk for oxygen desaturation. At least $60 \mathrm{~L} / \mathrm{min}$ of high-flow nasal cannula oxygen should be applied to allow higher $\mathrm{FI}_{\mathrm{O}_{2}}$ with a moderate level of PEEP.

$\underline{1}$

Audrey De Jong, M.D.

Samir Jaber, M.D., Ph.D.

Saint Eloi University Hospital and Montpellier School of Medicine Research Unit INSERM U1046

Montpellier, France

\section{References}

1. Semler MW, Janz DR, Lentz RJ, Matthews DT, Norman BC, Assad TR, Keriwala RD, Ferrell BA, Noto MJ, McKown AC, et al.; FELLOW Investigators and the Pragmatic Critical Care Research Group. Randomized trial of apneic oxygenation during endotracheal intubation of the critically ill. Am J Respir Crit Care Med 2016;193: 273-280.

2. Frumin MJ, Epstein RM, Cohen G. Apneic oxygenation in man. Anesthesiology 1959;20:789-798.

3. Jaber S, Amraoui J, Lefrant J-Y, Arich C, Cohendy R, Landreau L, Calvet Y, Capdevila X, Mahamat A, Eledjam J-J. Clinical practice and risk factors for immediate complications of endotracheal intubation in the intensive care unit: a prospective, multiple-center study. Crit Care Med 2006;34:2355-2361. 
4. Perbet S, De Jong A, Delmas J, Futier E, Pereira B, Jaber S, Constantin JM. Incidence of and risk factors for severe cardiovascular collapse after endotracheal intubation in the ICU: a multicenter observational study. Crit Care 2015;19:257.

5. Baillard C, Fosse J-P, Sebbane M, Chanques G, Vincent F, Courouble P, Cohen Y, Eledjam J-J, Adnet F, Jaber S. Noninvasive ventilation improves preoxygenation before intubation of hypoxic patients. Am J Respir Crit Care Med 2006;174:171-177.

6. Klompas M. Potential strategies to prevent ventilator-associated events. Am J Respir Crit Care Med 2015;192:1420-1430.

7. Engström J, Hedenstierna G, Larsson A. Pharyngeal oxygen administration increases the time to serious desaturation at intubation in acute lung injury: an experimental study. Crit Care 2010;14:R93.

8. Miguel-Montanes R, Hajage D, Messika J, Bertrand F, Gaudry S, Rafat C, Labbé V, Dufour N, Jean-Baptiste S, Bedet A, et al. Use of highflow nasal cannula oxygen therapy to prevent desaturation during tracheal intubation of intensive care patients with mild-to-moderate hypoxemia. Crit Care Med 2015;43:574-583.

9. Vourc'h M, Asfar P, Volteau C, Bachoumas K, Clavieras N, Egreteau PY, Asehnoune K, Mercat A, Reignier J, Jaber S, et al. High-flow nasal cannula oxygen during endotracheal intubation in hypoxemic patients: a randomized controlled clinical trial. Intensive Care Med 2015;41: 1538-1548.

10. Maggiore SM, Idone FA, Vaschetto R, Festa R, Cataldo A, Antonicelli F, Montini L, De Gaetano A, Navalesi P, Antonelli M. Nasal high-flow versus Venturi mask oxygen therapy after extubation. Effects on oxygenation, comfort, and clinical outcome. Am J Respir Crit Care Med 2014;190:282-288.
11. Chanques G, Riboulet F, Molinari N, Carr J, Jung B, Prades A, Galia F, Futier E, Constantin JM, Jaber S. Comparison of three high flow oxygen therapy delivery devices: a clinical physiological cross-over study. Minerva Anestesiol 2013;79:1344-1355.

12. Racine SX, Solis A, Hamou NA, Letoumelin P, Hepner DL, Beloucif S, Baillard C. Face mask ventilation in edentulous patients: a comparison of mandibular groove and lower lip placement. Anesthesiology 2010;112:1190-1193.

13. De Jong A, Molinari N, Terzi N, Mongardon N, Arnal J-M, Guitton C, Allaouchiche B, Paugam-Burtz C, Constantin J-M, Lefrant J-Y, et al.; AzuRéa Network for the Frida-Réa Study Group. Early identification of patients at risk for difficult intubation in the intensive care unit: development and validation of the MACOCHA score in a multicenter cohort study. Am J Respir Crit Care Med 2013;187:832-839.

14. De Jong A, Molinari N, Conseil M, Coisel Y, Pouzeratte Y, Belafia F, Jung $B$, Chanques $G$, Jaber $S$. Video laryngoscopy versus direct laryngoscopy for orotracheal intubation in the intensive care unit: a systematic review and meta-analysis. Intensive Care Med 2014;40: 629-639.

15. Rali P, Arshad H, Lamba T. Comparison of video laryngoscopy versus direct laryngoscopy during urgent endotracheal intubation; trial of the route of early nutritional support in critically ill adults; and transfusion of plasma, platelets, and red blood cells in a 1:1:1 versus a 1:1:2 ratio and mortality in patients with severe trauma. Am J Respir Crit Care Med 2015;192:892-894. 